\title{
Seed germination of three endangered subspecies of Discocactus Pfeiff. (Cactaceae) in response to environmental factors ${ }^{1}$
}

\author{
Joana Paula Bispo Nascimento², Marcos Vinicius Meiado ${ }^{2 *}$, José Alves Siqueira-Filho ${ }^{3}$
}

\begin{abstract}
Temperature, light, water availability and excessive salt in the soil are among the abiotic factors that most influence the germination process in semiarid ecosystems. The aim of the present study was to determine the effect of these abiotic factors on seed germination in three subspecies of cactus: Discocactus bahiensis, D. zehntneri subsp. petr-halfarii and D. zehntneri subsp. zehntneri. Seeds were set for germination under two light conditions (12-h light/dark photoperiod and continuous darkness) and 10 temperature treatments [eight constant temperatures $\left(10,15,20,25,30,35,40\right.$ and $\left.45^{\circ} \mathrm{C}\right)$ and two alternating temperatures $(30$ to $20^{\circ} \mathrm{C}$ and 35 to $25^{\circ} \mathrm{C}$ )]. Polyethylene Glycol (PEG) 6000 and sodium chloride $(\mathrm{NaCl})$ were used to simulate water and saline stress, respectively, with the following osmotic potentials: $0.0,-0.2,-0.4,-0.6,-0.8$ and $-1.0 \mathrm{MPa}$. Three subspecies were positive photoblastic. The optimum temperature for germination was 25 to $35^{\circ} \mathrm{C}$ for D. bahiensis and D. zehntneri subsp. zehntneri, and 30 to $35^{\circ} \mathrm{C}$ for D. zehntneri subsp. petr-halfarii. The seeds of all three subspecies exhibited tolerance to water and saline stress, as germination was observed at potentials for up to $-0.6 \mathrm{MPa}$ in the PEG and $\mathrm{NaCl}$ solutions.
\end{abstract}

Index terms: abiotic factors, caatinga, germinability, photoblastism, temperature.

\section{Germinação de sementes de três espécies de Discocactus Pfeiff. (Cactaceae) ameaçadas de extinção em resposta a fatores ambientais}

\begin{abstract}
RESUMO - Temperatura, luz, disponibilidade de água e sal excessivo no solo estão entre os fatores abióticos que mais influenciam o processo de germinação em ecossistemas semiáridos. O objetivo do presente estudo foi determinar o efeito desses fatores abióticos sobre a germinação de sementes em três subespécies de cactos: Discocactus bahiensis, D. zehntneri subsp. petr-halfarii e D. zehntneri subsp. zehntneri. As sementes foram colocadas para germinação sob duas condições de luz (fotoperíodo de 12 horas e escuro contínuo) e 10 tratamentos de temperatura [oito temperaturas constantes $\left(10,15,20,25,30,35,40\right.$ e $\left.45{ }^{\circ} \mathrm{C}\right)$ e duas temperaturas alternadas $\left(30 \mathrm{a} 20^{\circ} \mathrm{C}\right.$ e 35 a $\left.\left.25^{\circ} \mathrm{C}\right)\right]$. Foram utilizados polietilenoglicol (PEG) 6000 e cloreto de sódio $(\mathrm{NaCl})$ para simular o estresse hídrico e salino, respectivamente, com os seguintes potenciais osmóticos: 0,$0 ;-0,2 ;-0,4 ;-0,6 ;-0,8$ e -1,0 $\mathrm{MPa}$. As três subespécies são fotoblásticas positivas. A temperatura ótima de germinação foi de 25 a $35^{\circ} \mathrm{C}$ para $\mathrm{D}$. bahiensis e D. zehntneri subsp. zehntneri e 30 a $35^{\circ} \mathrm{C}$ para D. zehntneri subsp. petr-halfarii. As sementes das três subespécies exibiram tolerância ao estresse hídrico e salino, pois foi observada germinação em potenciais de até -0,6 MPa nas soluções de $\mathrm{PEG}$ e NaCl.
\end{abstract}

Termos para indexação: fatores abióticos, caatinga, germinabilidade, fotoblastismo, temperatura.

\section{Introduction}

Successful propagation of species lies in their ability to survive and reproduce. Particularly, among plant species, perpetuation depends on the germination capacity of diaspores (Baskin and Baskin, 2014). Seeds are influenced by several ecological factors and plants in arid and semiarid ecosystems

${ }^{1}$ Submitted on $07 / 22 / 2017$. Accepted for publication on $05 / 11 / 2018$. ${ }^{2}$ Laboratório de Fisiologia de Sementes, Universidade Federal de Sergipe, 49510-200 - Itabaiana, SE - Brasil. exhibit strategies for reproduction, such as phenological synchronization in the production and dispersal of seeds at times that are favorable to the establishment of new individuals (Meiado et al., 2012b). Moreover, water availability, light and temperature are important environmental factors that determine the germination of seeds dispersed in such environments (Meiado et al., 2012b; Baskin and Baskin, 2014).

${ }^{3}$ Laboratório de Sementes, Universidade Federal do Vale do São Francisco, 56306-410 - Petrolina, PE - Brasil.

*Corresponding author <meiado@ufs.br> 
Cacti are typical perennial plants in arid environments. Studies have reported the crucial influence of abiotic factors, especially light and temperature, on seed germination of cacti as well as the recruitment of seedlings (Rojas-Aréchiga and Mandujano, 2008; Meiado, 2012; Meiado et al., 2017). Abundance and broad distribution of this family in the Caatinga ecosystem, which is a Tropical Dry Forest located in Northeastern Brazil, may be, in part, related to the high production of fruits per individual as well as the high production of seeds per fruit and the seed germination under a broad range of environmental conditions (Meiado et al., 2010; 2016; 2017). Thus, understanding the influence of abiotic factors on seed germination of endangered species of cactus can contribute to the regeneration of natural populations. Such information can be used for the production of seedlings for subsequent reintroduction into communities of the Caatinga ecosystem.

Brazil is the third largest center of cactus diversity in the world (Taylor and Zappi, 2004), and more than 10\% of its species are endangered (Meiado et al., 2012a). Some of belong to the genus Discocactus Pfeiff. (Machado et al., 2005). According to Zappi et al. (2011), a species is considered rare when its populations are biologically viable, but naturally scarce and limited to its area of distribution and habitat specificity, with germination success dependent on the number of individuals that affect the distribution and abundance of such species.

Considering the current threats and pressures on natural cacti populations due mainly to human activities, such as deforestation, mining and illegal trade of species, studies on the germination capacity of seeds are essential to the adequate management of natural resources and conservation of these species (Zappi et al., 2011). Moreover, few studies have investigated abiotic factors that affect the germination of cacti seeds in Brazil (Meiado et al., 2017). Thus, knowledge on the eco-physiological aspects of seed germination in these species could contribute towards the understanding of the establishment and recruitment processes of cacti in arid and semiarid ecosystems, thereby contributing to conservation.

The aim of the present study was to answer the following questions: 1) what are the optimum conditions for seed germination of Discocactus subspecies? 2) How do the presence and absence of light and different temperature regimes affect seed germination? (3) Can seeds complete their germination process under water and saline stress?

\section{Material and Methods}

In Brazil, Cactaceae comprises 264 species distributed throughout all ecosystems in the country (Zappi et al., 2017), with about 95 species located in the Caatinga ecosystem, including species from genus Discocactus Pfeiff. (Meiado et al., 2012a; Zappi et al., 2017). This genus has 10 species distributed in the Caatinga, Cerrado (Savannah) and Pantanal (Wetland) ecosystems of Brazil (Machado et al., 2005; Zappi et al., 2017). However, most species are in the state of Bahia, in which a high degree of floristic endemism of the family Cactaceae is found (Taylor and Zappi, 2004), including three species of this genus: Discocactus bahiensis Britton \& Rose, D. catingicola Buining \& Brederoo and D. zehntneri Britton $\&$ Rose. The latter species has three subspecies: D. zehntneri subsp. boomianus (Buining \& Brederoo) N.P. Taylor \& Zappi, D. zehntneri subsp. petr-halfarii (Zachar) M.R. Santos \& M.C. Machado and D. zehntneri Britton \& Rose subsp. zehntneri (Santos et al., 2015). The present study included three of these four subspecies that occur in the Caatinga ecosystem: $D$. bahiensis, D. zehntneri subsp. petr-halfarii and D. zehntneri subsp. zehntneri.

This genus has flat, globose or discoid stems with a cephalium at the apex of the stem from which nocturnal white flowers emerge, which are pollinated by moths. The fruit exhibits a lateral dehiscence and varies in color from white to red, depending on the species (Machado et al., 2005). Discocactus zehntneri subsp. zehntneri is considered a rare subspecies with a distribution restricted to shallow soils and greater occurrence in areas of rocky outcrops in the semiarid region of the state of Bahia. Discocactus zehntneri subsp. petr-halfarii is constituted by a single population located in areas of shallow, stony soils in the municipality of Juazeiro (Santos et al., 2015). Discocactus bahiensis occurs in the state of Bahia as well as other states in Northeastern Brazil, such as Ceará, Pernambuco and Piauí (Zappi et al., 2017). However, the small number of known populations as well as the small number of individuals and habitat specificity limits these cacti to a restricted area.

Seeds were collected from the three subspecies of Discocactus studied in areas of Caatinga ecosystem in the municipalities of Juazeiro (Area $1-09^{\circ} 28^{\prime} 46.1$ ' S, $040^{\circ} 15^{\prime} 31.8^{\prime \prime} \mathrm{W}$, altitude: $395 \mathrm{~m}$ asl; Area $2-09^{\circ} 28^{\prime} 35.4^{\prime \prime} \mathrm{S}$, $040^{\circ} 34^{\prime} 44.4^{\prime \prime} \mathrm{W}$, altitude: $390 \mathrm{~m}$ asl) and Sento Sé (Area 3 - 09 $54^{\circ} 05.48^{\prime \prime} \mathrm{S}, 041^{\circ} 03^{\prime} 49.26^{\prime} \mathrm{W}$, altitude: $791 \mathrm{~m}$ asl) in the state of Bahia, Brazil. Seeds from D. zehntneri subsp. petr-halfarii were collected from Area 1, which has typical sclerophyllous vegetation of the Caatinga ecosystem and eutrophic, haplic, planosol soils (Brasil, 2006). Seeds from D. bahiensis were collected from Area 2, which has the same vegetation and edaphoclimatic characteristics as Area 1. Seeds from D. zehntneri subsp. zehntneri were collected from Area 3, which is mainly characterized by eutrophic, litolic, 
neosol soils (Brasil, 2006).

Effects of light, temperature, water and saline stress on seed germination were assessed for the three studied subspecies. All treatments were performed in B.O.D. germination chambers. The seeds were extracted from the fruits (100 fruits per species) and set to germinate immediately after harvest in Petri dishes ( $5 \mathrm{~cm}$ in diameter) containing filter paper moistened with $3 \mathrm{~mL}$ of the test solution corresponding to each treatment [distilled water (control), polyethylene glycol (PEG 6000) or sodium chloride $(\mathrm{NaCl})]$. The dishes were sealed with plastic wrap and no additional solution was added during the evaluation period. One hundred seeds were used for each treatment, which were distributed into four replicates of 25 seeds each, and protrusion of the radicle was the criterion used for the determination of seed germination.

For light and temperature studies, seeds were set to germinate using an entirely randomized design $(2 \times 10 \times 4)$ with two light conditions [12-h light/dark photoperiod (light intensity: $200 \mu \mathrm{mol} \times \mathrm{m}^{-2} \times \mathrm{s}^{-1}$ and continuous darkness simulated with the use of a black polypropylene plastic), 10 temperatures [eight constant temperatures $(10,15,20,25,30,35,40$ and $\left.45{ }^{\circ} \mathrm{C}\right)$ and two alternating temperatures $\left(30-20{ }^{\circ} \mathrm{C}\right.$ and 35 $\left.\left.25^{\circ} \mathrm{C}\right)\right]$ and four replicates for each species. In the treatments with alternating temperatures submitted to a 12-h light/dark photoperiod, the highest temperatures corresponded to the period of exposure to light. Seeds kept in continuous darkness were evaluated only at the end of the experiment, on day 30 after the onset of the experiment (Meiado et al., 2016). After this analysis, other treatments (water and saline stress) were conducted at the optimum germination temperature determined for each species (Meiado et al., 2010; 2016).

Commercial solutions of PEG 6000 (Villela et al., 1991) and $\mathrm{NaCl}$ (analytical grade) were used (Braccini et al., 1996) to simulate water and saline stress, respectively. Experiment was conducted in an entirely randomized factorial design $(2 \times 6 \times 4)$ with two light conditions [white light with a 12-h light/dark photoperiod (light intensity: $200 \mu \mathrm{mol} \times \mathrm{m}^{-2} \times \mathrm{s}^{-1}$ ) and continuous darkness (achieved with a black polyethylene bag)], six osmotic potentials [0.0 (distilled water), $-0.2,-0.4,-0.6,-0.8$ and $-1.0 \mathrm{MPa}$ ] and four replicates for each subspecies. Osmotic potential was calculated based on Villela et al. (1991) and Braccini et al. (1996) with the aid of an osmometer (Mark 3, Fiske Associates, Norwood, USA) at the onset of the experiment. Germination was evaluated daily for 30 days. The seeds maintained in darkness were only evaluated on day 30 after the onset of the experiment (Meiado et al., 2016).

At the end of the experiments, germinability (\%), mean germination time $\left[t=\sum n_{i} t / \sum n_{i}\right.$, in which $t_{i}$ is the time since the onset of the experiment to the $n^{\text {th }}$ observation (days) and $n_{i}$ is the number of seed germinated in time $i$ (not the accumulated number, but the number corresponding to the nth observation)], the emergence rate index $\left[\mathrm{ERI}=\left(\mathrm{G}_{1} / \mathrm{N}_{1}\right)\right.$ $+\left(\mathrm{G}_{2} / \mathrm{N}_{2}\right)+\ldots+\left(\mathrm{G}_{\mathrm{n}} / \mathrm{N}_{\mathrm{n}}\right)$, in which $\mathrm{G}_{1}, \mathrm{G}_{2}$ and $\mathrm{G}_{\mathrm{n}}$ correspond to the number of seeds germinated at the first, second and last count, respectively, and $\mathrm{N}_{1}, \mathrm{~N}_{2}$ and $\mathrm{N}_{\mathrm{n}}$ represent the number of days elapsed to the first, second and last count, respectively] and the synchronization index $\left[E=-\sum f_{i} \cdot \log _{2} f_{i}\right.$, in which $f i$ is the relative germination frequency (i.e., the proportion of seeds germinated in a time interval)] were calculated in the GerminaQuant 1.0 software (Marques et al., 2015)]. The temperature treatment that provided the highest germinability in the shortest time was selected as the optimum germination temperature for the subspecies analyzed (Meiado et al., 2016).

Treatments with less than 5\% germinability were excluded from the analysis due to the influence of the low number of germinated seeds on the determination of mean germination time, emergence rate index and synchronization index (Meiado et al., 2010; 2016). Germinability was transformed into arcsine $\sqrt{ } \%$. Data were submitted to analysis of variance (OneWay ANOVA) and means were compared using Tukey's test. When data did not meet the requirements for parametric tests, the non-parametric Kruskal-Wallis test was used with the Newman-Keuls post hoc test (Zar, 2010). Shapiro-Wilk and Levene tests were used to determine the normality of the data and homogeneity of variances, respectively (Zar, 2010). All statistical analyses were performed with Bio Estat 5.0 program, with the level of significance set to 5\% (Ayres et al., 2007).

\section{Results and Discussion}

With respect to light treatment, no germination occurred in the experiments with continuous darkness and seeds of the three subspecies of Discocactus were classified as positive photoblastic. Light is one of the most important abiotic factors that affect the control of different life phases in plants, such as germination and seedling establishment (Baskin and Baskin, 2014). Photoblastic response and light requirements for seed germination in Cactaceae are related to different phylogenetic and biological attributes in these plants (Rojas-Aréchiga and Vázquez-Yanes, 2000; Meiado, 2012; Rojas-Aréchiga et al., 2013). According to Meiado et al. (2016), cacti in Brazilian ecosystems exhibit two distinct behaviors regarding the response to light during germination: seeds produced by the subfamily Cactoideae only germinate in the presence of light and are therefore positive photoblastic, whereas seeds that germinate in both the presence and absence of light are known as photoblastic neutral, as occurs with cacti in Brazil that belong to the subfamilies Opuntioideae and Pereskioideae. The three studied subspecies belong to subfamily Cactoideae and were 
classified as positive photoblastic. This finding agrees with data described in previous studies, in which similar behavior is described for cacti that occur in the Caatinga as well as other ecosystems (Rojas-Aréchiga and Vázquez-Yanes, 2000; Gurvich et al., 2008; Meiado, 2012; 2016; Meiado et al., 2012b; 2016; Abud et al., 2013; Rojas-Aréchiga et al., 2013).

According to some authors, life form in cacti could be related to photoblastism (Rojas-Aréchiga et al., 1997; Flores et al., 2011). Moreover, Rojas-Aréchiga et al. (1997) demonstrated that globose or barrel-shaped cacti, such as species of the genus Discocactus analyzed in the present study, are positive photoblastic, whereas columnar cacti may be either positive photoblastic or neutral. This is in agreement with data reported in previous studies regarding the response to light in relation to the life form of cacti (Cheib and Garcia, 2012; Gurvich et al., 2008; Meiado et al., 2010; Meiado, 2012). Photoblastic response pattern is believed to be related to the distance between fruit production and the soil, as higher temperatures near the soil are thought to determine positive photoblastism in a given species (Rojas-Aréchiga et al., 1997).

In temperature treatments, $D$. bahiensis and D. zehntneri subsp. zehntneri exhibited higher germinability when the temperature was between 25 and $35{ }^{\circ} \mathrm{C}$, with significant differences found among all temperature treatments $(D$. bahiensis: $\mathrm{H}=37.2796, \mathrm{df}=9, \mathrm{p}<0.0001 ; D$. zehntneri subsp. zehntneri: $\mathrm{H}=37.6352$, df $=9, \mathrm{p}<0.0001$ ) (Table 1). $D$. zehntneri subsp. petr-halfarii exhibited similar germination in the 25 to $40{ }^{\circ} \mathrm{C}$ temperature range, with significant differences found among the different temperature treatments $(\mathrm{H}=$ 34.9129, $\mathrm{df}=9, \mathrm{p}<0.0001)$ (Table 1). In addition, Table 1 also show high seed germination of $D$. bahiensis and $D$. zehntneri subsp. zehntneri at the alternating temperatures.

The optimum germination temperatures for $D$. bahiensis were 25,30 and $35^{\circ} \mathrm{C}$, based on the greater germinability within a significantly shorter mean germination time $(\mathrm{F}=35.4103, \mathrm{df}$ $=7, \mathrm{p}=<0.0001)$ and with a smaller synchronization index $(\mathrm{F}=$ $3.3677, \mathrm{df}=7, \mathrm{p}=0.0121$ ) at this temperature. A germinability higher than $90 \%$ within a broad range of constant temperatures ( 25 to $40{ }^{\circ} \mathrm{C}$ ) was found for D. zehntneri subsp. petr-halfarii (Table 1), with an optimum germination temperatures of 30 and $35^{\circ} \mathrm{C}$, as evidenced by the greater germinability, shorter mean germination time $(\mathrm{H}=25.7277, \mathrm{df}=7, \mathrm{p}=0.006)$ and smaller emergence rate index $(H=20.3011, d f=7, p=0.005)$. The optimum germination temperatures for $D$. zehntneri subsp. zehntneri were 25,30 and $35^{\circ} \mathrm{C}$, as evidenced by the greater germinability, mean germination time $(\mathrm{F}=5.1371, \mathrm{df}=7, \mathrm{p}$ $=0.0014)$ and synchronization index $(\mathrm{F}=14.4789, \mathrm{df}=7, \mathrm{p}$ $<0.0001$ ), with no significant difference between the two temperatures (Table 1).
Among the three subspecies analyzed in the present study, germination did not occur at the lowest temperature tested $\left(10^{\circ} \mathrm{C}\right)$ and was reduced at temperatures of 40 and $45{ }^{\circ} \mathrm{C}$. These findings agree with data reported for other cacti species and demonstrate that seeds from the genus Discocactus are able to germinate between 15 and $40{ }^{\circ} \mathrm{C}$, with optimum germination occurring between 25 and 35 ${ }^{\circ} \mathrm{C}$. Similar findings are reported by Gurvich et al. (2008) for endemic globose cacti in Argentina belonging to the genus Gymnocalycium Pfeiff. ex Mittler, which did not germinate at temperatures of 5 to $15{ }^{\circ} \mathrm{C}$ and obtain the best results at temperatures of 25 to $35^{\circ} \mathrm{C}$. Analyzing the effect of temperature on the germinability of seeds of the columnar cactus Cereus jamacaru DC. subsp. jamacaru, Meiado et al. (2010) reported an optimum temperature ranging from 25 to $30{ }^{\circ} \mathrm{C}$, with faster germination at $30^{\circ} \mathrm{C}$ and no germination at $10{ }^{\circ} \mathrm{C}$. Likewise, Cheib and Garcia (2012) report a lack of germination at $10{ }^{\circ} \mathrm{C}$ and optimum germination between 20 and $30{ }^{\circ} \mathrm{C}$ for four species of the columnar genus Arthrocereus A. Berger. On the other hand, seeds of several species of Melocactus Link and Otto, a globose and subglobose genus of Cactaceae, have higher germinability and lower mean germination time in $30{ }^{\circ} \mathrm{C}$ (Meiado et al., 2016). An exception is Melocactus violaceus Pfeiff. subsp. violaceus from the Atlantic Forest of Brazil which has an optimum temperature between 20 and $25^{\circ} \mathrm{C}$ (Meiado et al., 2016).

Present findings reveal that globose, discoid cacti are also capable of germinating at elevated temperatures. The species distribution may help explain the high germinability of $D$. zehntneri subsp. petr-halfarii at higher temperatures (30 to 40 ${ }^{\circ} \mathrm{C}$ ), as this subspecies is respectively distributed among rocky soils with no vegetal coverage and rocky outcrops, where the temperature is often high (Santos et al., 2015). In contrast, D. bahiensis occurs in soils with vegetal coverage, which provides some degree of shade and this species consequently responds better to somewhat cooler temperature $\left(20\right.$ to $\left.25^{\circ} \mathrm{C}\right)$. According to Gurvich et al. (2008), the preference of species for specific habitats should be taken into consideration when analyzing seed germination in relation to temperature.

Although some studies have demonstrated that the requirement of alternating temperatures is common among species in arid and semiarid ecosystems (Meiado et al., 2012b), Martins et al. (2012) found that a constant temperature was more favorable to the germination of seeds from Pilosocereus arrabidae (Lem.) Byles and Rowley. This support the present findings regarding all three subspecies of Discocactus analyzed, for which a constant temperature led to optimum germination (for more examples of studies that reported a higher seed germination of cacti species 
Table 1. Germinability (\%), mean germination time (days), emergence rate index and synchronization index of Discocactus bahiensis, Discocactus zehntneri subsp. petr-halfarii and Discocactus zehntneri subsp. zehntneri (Cactaceae) submitted to different constant and alternating temperature treatments with a 12-hour light/dark photoperiod.

\begin{tabular}{|c|c|c|c|c|}
\hline $\begin{array}{c}\text { Temperature } \\
\left({ }^{\circ} \mathrm{C}\right)\end{array}$ & $\begin{array}{c}\text { Germinability } \\
(\%)\end{array}$ & $\begin{array}{c}\text { Mean germination time } \\
\text { (days) }\end{array}$ & Emergence rate index & Synchronization index \\
\hline & \multicolumn{4}{|c|}{ Discocactus bahiensis } \\
\hline 10 & - & - & - & - \\
\hline 15 & $25.5 \pm 2.1 \mathrm{c}$ & $9.5 \pm 0.4 \mathrm{a}$ & $7.3 \pm 0.3 \mathrm{a}$ & $3.0 \pm 0.3 \mathrm{a}$ \\
\hline 20 & $80.0 \pm 4.1 \mathrm{~b}$ & $7.5 \pm 0.6 b$ & $7.0 \pm 0.2 \mathrm{a}$ & $2.6 \pm 0.3 \mathrm{ab}$ \\
\hline 25 & $93.0 \pm 1.4 \mathrm{a}$ & $5.8 \pm 0.5 \mathrm{c}$ & $7.0 \pm 0.3 \mathrm{a}$ & $2.6 \pm 0.1 \mathrm{ab}$ \\
\hline 30 & $95.0 \pm 1.3 \mathrm{a}$ & $5.2 \pm 0.2 \mathrm{c}$ & $7.2 \pm 0.5 \mathrm{a}$ & $2.4 \pm 0.2 \mathrm{~b}$ \\
\hline 35 & $93.0 \pm 1.3 \mathrm{a}$ & $6.0 \pm 0.7 \mathrm{c}$ & $7.1 \pm 0.5 \mathrm{a}$ & $2.5 \pm 0.4 \mathrm{ab}$ \\
\hline 40 & $15.0 \pm 2.6 \mathrm{~d}$ & $7.8 \pm 0.5 \mathrm{~b}$ & $7.5 \pm 0.3 \mathrm{a}$ & $3.0 \pm 0.1 \mathrm{a}$ \\
\hline 45 & - & - & - & - \\
\hline $30-20$ & $85.0 \pm 4.9 \mathrm{ab}$ & $7.7 \pm 0.3 b$ & $7.4 \pm 0.5 \mathrm{a}$ & $2.7 \pm 0.2 \mathrm{ab}$ \\
\hline \multirow[t]{2}{*}{$35-25$} & $90.0 \pm 2.3 \mathrm{a}$ & $7.3 \pm 0.3 \mathrm{~b}$ & $7.2 \pm 0.2 \mathrm{a}$ & $2.8 \pm 0.8 \mathrm{ab}$ \\
\hline & \multicolumn{4}{|c|}{ Discocactus zehntneri subsp. petr-halfarii } \\
\hline 10 & - & - & - & - \\
\hline 15 & $12.0 \pm 6.0 \mathrm{~d}$ & $5.9 \pm 11.8 \mathrm{bc}$ & $0.1 \pm 0.1 \mathrm{~d}$ & $0.1 \pm 0.1 \mathrm{c}$ \\
\hline 20 & $66.0 \pm 8.3 b$ & $12.5 \pm 1.6 \mathrm{a}$ & $1.4 \pm 0.1 \mathrm{~cd}$ & $2.8 \pm 0.5 \mathrm{ab}$ \\
\hline 25 & $94.0 \pm 2.3 \mathrm{a}$ & $8.6 \pm 1.0 \mathrm{ab}$ & $2.8 \pm 2.2 \mathrm{bc}$ & $2.1 \pm 0.2 \mathrm{~b}$ \\
\hline 30 & $97.0 \pm 3.0 \mathrm{a}$ & $4.1 \pm 0.3 \mathrm{c}$ & $8.5 \pm 0.9 \mathrm{a}$ & $2.5 \pm 0.1 \mathrm{ab}$ \\
\hline 35 & $94.0 \pm 6.0 \mathrm{a}$ & $5.0 \pm 0.5 \mathrm{bc}$ & $5.1 \pm 0.7 \mathrm{~b}$ & $2.0 \pm 0.3 \mathrm{~b}$ \\
\hline 40 & $92.0 \pm 4.6 \mathrm{a}$ & $7.5 \pm 0.1 \mathrm{~b}$ & $3.2 \pm 0.2 \mathrm{bc}$ & $2.7 \pm 0.2 \mathrm{ab}$ \\
\hline 45 & $61.0 \pm 2.0 \mathrm{~b}$ & $10.0 \pm 2.1 \mathrm{a}$ & $2.3 \pm 0.6 \mathrm{bc}$ & $3.0 \pm 0.1 \mathrm{a}$ \\
\hline $30-20$ & $47.0 \pm 2.4 \mathrm{c}$ & $10.6 \pm 2.0 \mathrm{a}$ & $1.1 \pm 0.4 \mathrm{~cd}$ & $2.1 \pm 0.4 \mathrm{~b}$ \\
\hline \multirow[t]{2}{*}{$35-25$} & $62.0 \pm 2.6 \mathrm{~b}$ & $8.4 \pm 1.0 \mathrm{ab}$ & $2.0 \pm 0.3 \mathrm{bc}$ & $2.5 \pm 0.1 \mathrm{ab}$ \\
\hline & \multicolumn{4}{|c|}{ Discocactus zehntneri subsp. zehntneri } \\
\hline 10 & - & - & - & - \\
\hline 15 & $10.0 \pm 4.1 \mathrm{~d}$ & $6.8 \pm 1.2 \mathrm{a}$ & $7.0 \pm 0.4 \mathrm{a}$ & $2.4 \pm 0.2 \mathrm{a}$ \\
\hline 20 & $65.0 \pm 2.6 b$ & $6.5 \pm 0.6 \mathrm{ab}$ & $6.8 \pm 0.4 \mathrm{a}$ & $1.9 \pm 0.1 \mathrm{~b}$ \\
\hline 25 & $90.0 \pm 2.8 \mathrm{a}$ & $5.5 \pm 0.4 \mathrm{ab}$ & $7.0 \pm 0.3 \mathrm{a}$ & $1.7 \pm 0.2 \mathrm{bc}$ \\
\hline 30 & $98.0 \pm 1.6 \mathrm{a}$ & $5.2 \pm 0.3 \mathrm{~b}$ & $6.6 \pm 0.3 \mathrm{a}$ & $1.6 \pm 0.2 \mathrm{bc}$ \\
\hline 35 & $99.0 \pm 1.0 \mathrm{a}$ & $4.9 \pm 0.3 b$ & $6.9 \pm 0.5 \mathrm{a}$ & $1.4 \pm 0.1 \mathrm{c}$ \\
\hline 40 & $55.0 \pm 3.4 \mathrm{c}$ & $5.6 \pm 0.8 \mathrm{ab}$ & $7.1 \pm 0.2 \mathrm{a}$ & $2.0 \pm 0.1 \mathrm{~b}$ \\
\hline 45 & - & - & - & - \\
\hline $30-20$ & $85.0 \pm 5.0 \mathrm{a}$ & $6.8 \pm 0.6 \mathrm{a}$ & $6.9 \pm 0.2 \mathrm{a}$ & $1.8 \pm 0.2 b$ \\
\hline $35-25$ & $90.0 \pm 1.6 \mathrm{a}$ & $5.8 \pm 0.5 \mathrm{ab}$ & $7.0 \pm 0.2 \mathrm{a}$ & $1.6 \pm 0.2 \mathrm{bc}$ \\
\hline
\end{tabular}

(-) No seed germination.

*Means followed by same letter in column do not differ significantly ( $5 \%$ level of significance, Tukey’s test or Newman-Keuls test).

under constant temperatures see Rojas-Aréchiga et al., 1998; Ortega-Baes and Rojas-Aréchiga, 2007; Ortega-Baes et al., 2011 and Souza et al., 2016).

Seed germination occurred in the different solutions of PEG 6000 under white light (Figure 1A). However, significant reductions in the germinability were found with an increase in the concentration of PEG 6000 . For D. bahiensis, the germinability reduced from $83.0 \pm 6.8 \%$ in the control treatment to $7.0 \pm 3.8 \%$ at the concentration of $-0.6 \mathrm{MPa}$ $(\mathrm{H}=21.7108$, df $=5, \mathrm{p}=0.0006)$. For D. zehntneri subsp. zehntneri, the germinability reduced from $98.0 \pm 4.0 \%$ in the control treatment to $4.0 \pm 4.6 \%$ at the concentration of $-0.6(\mathrm{H}$ $=19.7674, \mathrm{df}=5, \mathrm{p}=0.0014)$. For D. zehntneri subsp. petrhalfarii, the germinability reduced from $97.0 \pm 3.8 \%$ in the control treatment to $3.0 \pm 3.8 \%$ at the concentration of -0.6 $\operatorname{MPa}(\mathrm{H}=20.2778, \mathrm{df}=5, \mathrm{p}=0.0011)$.

Despite the reduction in the germinability with the increase in the concentration of PEG 6000, significant differences were found in the -0.2 and $-0.4 \mathrm{MPa}$ treatments in comparison to the control (D. bahiensis: $\mathrm{p}=0.4237$ and $\mathrm{p}$ 

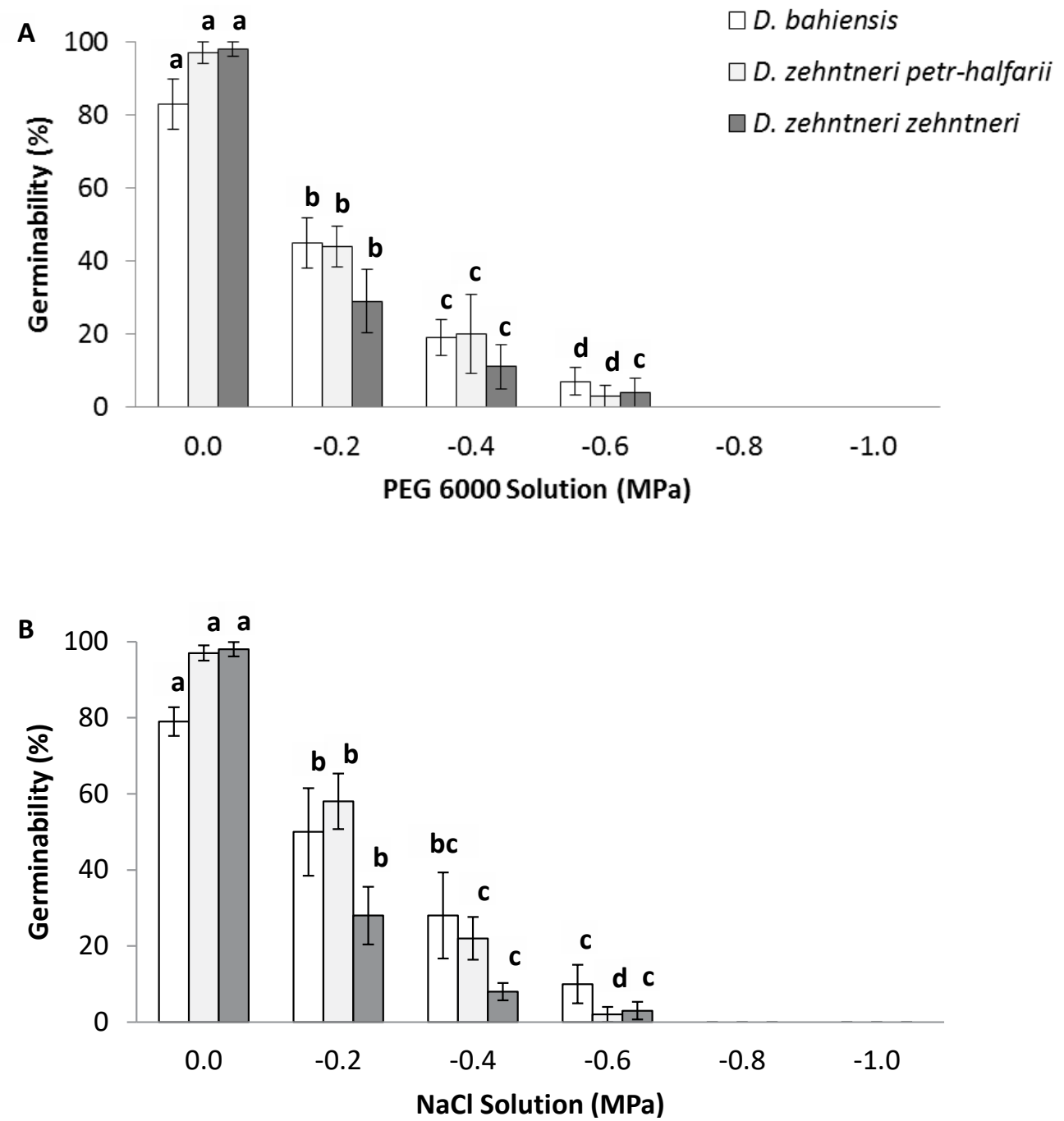

Figure 1. Germinability (mean \pm standard deviation) of seeds from Discocactus bahiensis, Discocactus zehntneri subsp. petrhalfarii and Discocactus zehntneri subsp. zehntneri (Cactaceae) from the Caatinga ecosystem in the state of Bahia (Brazil) submitted to different water (A) and saline (B) stress treatments. Lowercase letters indicate significant difference between potentials in the same species ( $5 \%$ level of significance, Tukey's test or Newman-Keuls test).

$=0.1042 ;$ D. zehntneri subsp. petr-halfarii: $\mathrm{p}=0.4094$ and $\mathrm{p}$ $=0.1153 ;$ D. zehntneri subsp. zehntneri: $\mathrm{p}=0.4237$ and $\mathrm{p}=$ 0.0801 , respectively) (Figure 1A). Nonetheless, water stress significantly affected mean germination time (D. bahiensis: $\mathrm{F}=62.9192$, df $=3, \mathrm{p}=0.0001 ; D$. zehntneri subsp. petrhalfarii: $\mathrm{F}=5.8893$, df $=2, \mathrm{p}=0.0229 ;$ D. zehntneri subsp. zehntneri: $\mathrm{F}=3.7174$, $\mathrm{df}=2, \mathrm{p}=0.0065)$ and the emergence rate index (D. bahiensis: $\mathrm{H}=14.1384$, $\mathrm{df}=3, \mathrm{p}=0.0027$; D. zehntneri subsp. petr-halfarii: $\mathrm{F}=146.0845$, $\mathrm{df}=2, \mathrm{p}=$ $0.0001 ;$ D. zehntneri subsp. zehntneri: $\mathrm{H}=9.8462$, $\mathrm{df}=2$, $\mathrm{p}=0.0073$ ). The negative changes in these indices with the reduction in water availability demonstrate a reduction in the number of seeds germinated as well as a longer germination times, with the exception of D. zehntneri subsp. petr-halfarii that presented the same mean germination time independently of the water stress treatment, with a tendency to increase as the stress increased. The synchronization index was also significantly affected by the reduction in water availability (D. bahiensis: $\mathrm{F}=43.0501, \mathrm{df}=3, \mathrm{p}=0.0001 ;$ D. zehntneri subsp. petr-halfarii: $\mathrm{H}=8.0281$, $\mathrm{df}=2, \mathrm{p}=0.0181 ; D$. zehntneri subsp. zehntneri: $\mathrm{H}=8.4645$, $\mathrm{df}=2, \mathrm{p}=0.0145$ ), demonstrating that the seeds germinated in a less synchronized way and within a longer time interval that could be two to three times greater (Table 2).

In the saline stress experiments, a reduction in the germinability was found with the increase in $\mathrm{NaCl}$ concentration for all three subspecies (D. bahiensis: $\mathrm{H}=$ 21.3171, $\mathrm{df}=5, \mathrm{p}=0.0007 ;$ D. zehntneri subsp. petr-halfarii: 
Table 2. Mean germination time (days), emergence rate index and synchronization index of Discocactus bahiensis, Discocactus zehntneri subsp. petr-halfarii and Discocactus zehntneri subsp. zehntneri (Cactaceae) submitted to different water stress treatments at a constant temperature of $30^{\circ}$ with a 12-hour light/dark photoperiod.

\begin{tabular}{|c|c|c|c|}
\hline $\begin{array}{l}\text { Water stress } \\
(\mathrm{MPa})\end{array}$ & $\begin{array}{l}\text { Mean germination time } \\
\text { (days) }\end{array}$ & $\begin{array}{l}\text { Emergence rate } \\
\text { index }\end{array}$ & $\begin{array}{c}\text { Synchronization } \\
\text { index }\end{array}$ \\
\hline \multicolumn{4}{|c|}{ Discocactus bahiensis } \\
\hline 0.0 & $9.16 \pm 1.38 \mathrm{a}$ & $2.71 \pm 0.56 \mathrm{a}$ & $2.91 \pm 0.34 \mathrm{a}$ \\
\hline-0.2 & $12.90 \pm 1.11 \mathrm{ab}$ & $1.22 \pm 0.30 \mathrm{ab}$ & $2.65 \pm 0.45 \mathrm{ab}$ \\
\hline-0.4 & $18.50 \pm 1.20 \mathrm{~b}$ & $0.26 \pm 0.06 \mathrm{bc}$ & $1.05 \pm 0.21 \mathrm{bc}$ \\
\hline-0.6 & $18.40 \pm 0.83 \mathrm{~b}$ & $0.09 \pm 0.04 \mathrm{c}$ & $0.75 \pm 0.27 \mathrm{c}$ \\
\hline-0.8 & - & - & - \\
\hline-1.0 & - & - & - \\
\hline \multicolumn{4}{|c|}{ Discocactus zehntneri subsp. petr-halfarii } \\
\hline 0.0 & $4.12 \pm 0.32 \mathrm{a}$ & $8.58 \pm 0.97 \mathrm{a}$ & $2.52 \pm 0.04 \mathrm{a}$ \\
\hline-0.2 & $6.44 \pm 1.27 \mathrm{a}$ & $1.91 \pm 0.28 \mathrm{ab}$ & $2.40 \pm 0.54 \mathrm{ab}$ \\
\hline-0.4 & $6.84 \pm 1.64 \mathrm{a}$ & $0.85 \pm 0.64 \mathrm{bc}$ & $1.31 \pm 0.35 \mathrm{bc}$ \\
\hline-0.6 & $11.20 \pm 13.00 \mathrm{a}$ & $0.03 \pm 0.04 \mathrm{c}$ & $0.01 \pm 0.01 \mathrm{c}$ \\
\hline-0.8 & - & - & - \\
\hline-1.0 & - & - & - \\
\hline \multicolumn{4}{|c|}{ Discocactus zehntneri subsp. zehntneri } \\
\hline 0.0 & $5.81 \pm 1.03 \mathrm{a}$ & $6.40 \pm 1.77 \mathrm{a}$ & $3.14 \pm 0.12 \mathrm{a}$ \\
\hline-0.2 & $7.62 \pm 1.48 b$ & $1.06 \pm 0.39 \mathrm{ab}$ & $2.15 \pm 0.67 \mathrm{ab}$ \\
\hline-0.4 & $7.37 \pm 1.16 \mathrm{c}$ & $0.37 \pm 0.17 b c$ & $1.37 \pm 0.75 b c$ \\
\hline-0.6 & $11.00 \pm 12.70 \mathrm{~d}$ & $0.04 \pm 0.05 \mathrm{c}$ & $0.01 \pm 0.01 \mathrm{c}$ \\
\hline-0.8 & - & - & - \\
\hline-1.0 & - & - & - \\
\hline
\end{tabular}

(-) No seed germination.

*Means followed by same letter in column do not differ significantly ( $5 \%$ level of significance, Tukey's test or Newman-Keuls test).

$\mathrm{H}=20.3643, \mathrm{df}=5, \mathrm{p}=0.0011 ;$ D. zehntneri subsp. zehntneri: $\mathrm{H}=20.6252, \mathrm{df}=5, \mathrm{p}=0.001$, Figure 1B), however, the differences were non-significant in the -0.2 and $-0.4 \mathrm{MPa}$ treatments in comparison to $0.0 \mathrm{MPa}$ (D. bahiensis: $\mathrm{p}=0.3173$ and $\mathrm{p}=0.1615 ;$ D. zehntneri subsp. petr-halfarii: $\mathrm{p}=0.4237$ and $\mathrm{p}=0.1096 ;$ D. zehntneri subsp. zehntneri: $\mathrm{p}=0.4237$ and $\mathrm{p}=0.0801$, respectively) (Figure 1B). The increase in saline concentration significantly affected mean germination time of two subspecies (D. bahiensis: $\mathrm{F}=22.8988, \mathrm{df}=3, \mathrm{p}=0.0001$; D. zehntneri subsp. zehntneri: $\mathrm{F}=6.514, \mathrm{df}=2, \mathrm{p}=0.0177$ ) and the emergence rate index (D. bahiensis: $\mathrm{F}=101.5853$, $\mathrm{df}=3, \mathrm{p}<0.0001 ; D$. zehntneri subsp. petr-halfarii: $\mathrm{H}=$ 9.8462, $\mathrm{df}=2, \mathrm{p}=0.0073 ; D$. zehntneri subsp. zehntneri: $\mathrm{H}$ $=9.8462, \mathrm{df}=2, \mathrm{p}=0.0073)$, demonstrating a reduction in germinability as well as a slower germination. Salinity also exerted a negative influence on the synchronization index ( $D$. bahiensis: $\mathrm{F}=16.4936, \mathrm{df}=3, \mathrm{p}=0.0003 ; D$. zehntneri subsp. petr-halfarii: $\mathrm{H}=6.5, \mathrm{df}=2, \mathrm{p}=0.0388 ; D$. zehntneri subsp. zehntneri: $\mathrm{H}=8.7692$, df $=2, \mathrm{p}=0.0125$ ), demonstrating slower, less synchronized germination among the three subspecies at high concentrations of $\mathrm{NaCl}$ (Table 3 ).

The present findings demonstrate that seeds of the three subspecies analyzed are tolerant to water and saline stress, as germination occurred in solutions with potentials of -0.6 $\mathrm{MPa}$. However, germinability decreased with the increase in the concentration of these solutions, which agrees with data reported for other cacti. Ramírez-Padilla and Valverde (2005) found a significant reduction in germinability of seeds from three species of the genus Neobuxbaumia Backeb. beginning at $-0.4 \mathrm{MPa}$. Germination of the three subspecies analyzed at higher saline levels $(-0.6 \mathrm{MPa})$ indicates that these subspecies are halotolerant and well-adapt to saline soils, which are often found in the Caatinga ecosystem (Fassbender and Bornemisza, 1987; Mascarenhas et al., 2005). Seeds of $C$. jamacaru subsp. jamacaru present a high germinability under the influence of saline stress, indicating that this species, which is abundant in semiarid areas of northeastern Brazil, and can also be considered halotolerant. 
Table 3. Mean germination time (days), emergence rate index and synchronization index of Discocactus bahiensis, Discocactus zehntneri subsp. petr-halfarii and Discocactus zehntneri subsp. zehntneri (Cactaceae) submitted to different saline stress treatments at a constant temperature of $30^{\circ}$ with a 12-hour light/dark photoperiod.

\begin{tabular}{|c|c|c|c|}
\hline $\begin{array}{l}\text { Saline stress } \\
\text { (MPa) }\end{array}$ & $\begin{array}{c}\text { Mean germination time } \\
\text { (days) }\end{array}$ & $\begin{array}{l}\text { Emergence rate } \\
\text { index }\end{array}$ & $\begin{array}{l}\text { Synchronization } \\
\text { index }\end{array}$ \\
\hline \multicolumn{4}{|c|}{ Discocactus bahiensis } \\
\hline 0.0 & $7.64 \pm 1.54 \mathrm{a}$ & $3.31 \pm 0.39 \mathrm{a}$ & $3.03 \pm 0.34 \mathrm{a}$ \\
\hline-0.2 & $10.70 \pm 2.25 \mathrm{ab}$ & $1.48 \pm 0.25 \mathrm{ab}$ & $2.29 \pm 0.41 \mathrm{ab}$ \\
\hline-0.4 & $14.90 \pm 1.16 \mathrm{bc}$ & $0.55 \pm 0.28 \mathrm{bc}$ & $1.60 \pm 0.54 \mathrm{bc}$ \\
\hline-0.6 & $16.20 \pm 1.45 \mathrm{c}$ & $0.16 \pm 0.09 \mathrm{c}$ & $0.84 \pm 0.51 \mathrm{c}$ \\
\hline-0.8 & - & - & - \\
\hline-1.0 & - & - & - \\
\hline \multicolumn{4}{|c|}{ Discocactus zehntneri subsp. petr-halfarii } \\
\hline 0.0 & $4.12 \pm 0.32 \mathrm{a}$ & $8.58 \pm 0.97 \mathrm{a}$ & $2.52 \pm 0.04 \mathrm{a}$ \\
\hline-0.2 & $8.10 \pm 0.42 \mathrm{a}$ & $2.06 \pm 0.37 \mathrm{ab}$ & $2.56 \pm 0.32 \mathrm{ab}$ \\
\hline-0.4 & $7.02 \pm 0.63 \mathrm{a}$ & $0.83 \pm 0.13 \mathrm{bc}$ & $1.81 \pm 0.60 \mathrm{abc}$ \\
\hline-0.6 & $9.25 \pm 10.70 \mathrm{a}$ & $0.02 \pm 0.03 \mathrm{c}$ & $0.01 \pm 0.01 \mathrm{c}$ \\
\hline-0.8 & - & - & - \\
\hline-1.0 & - & - & - \\
\hline \multicolumn{4}{|c|}{ Discocactus zehntneri subsp. zehntneri } \\
\hline 0.0 & $5.81 \pm 1.03 \mathrm{a}$ & $6.40 \pm 1.77 \mathrm{a}$ & $3.14 \pm 0.12 \mathrm{a}$ \\
\hline-0.2 & $9.34 \pm 2.23 b$ & $0.85 \pm 0.28 \mathrm{ab}$ & $1.97 \pm 0.19 \mathrm{ab}$ \\
\hline-0.4 & $11.10 \pm 2.76 \mathrm{c}$ & $0.17 \pm 0.08 \mathrm{~b}$ & $0.50 \pm 1.00 \mathrm{bc}$ \\
\hline-0.6 & $11.20 \pm 7.63 \mathrm{~d}$ & $0.05 \pm 0.03 \mathrm{~b}$ & $0.01 \pm 0.01 \mathrm{bc}$ \\
\hline-0.8 & - & - & - \\
\hline-1.0 & - & - & - \\
\hline
\end{tabular}

(-) No seed germination.

*Means followed by same letter in column do not differ significantly ( $5 \%$ level of significance, Tukey's test or Newman-Keuls test).

\section{Conclusions}

The present findings demonstrate that three subspecies of Discocactus, although endangered, are capable of germinating in a wide range of environmental factors and behave similarly to other species of Cactaceae that inhabit semiarid areas of Brazil. However, despite germination in a wide range of abiotic factors, the three subspecies are restricted to small populations with a small number of individuals, which contributes to their endangered status. It is clear that these subspecies have a temperature tolerance range between 25 and $35{ }^{\circ} \mathrm{C}$. However, the temperature of the soil surface reaches much higher temperatures, even during the rainy season when the seeds germinate in the Caatinga. Thus, temperature would be one of the main filters that reduce the number, speed and synchrony of seed germination of these subspecies. Finally, the present study provides essential information for ex situ conservation programs, as seedlings could be produced in a laboratory setting or nursery, thereby contributing to the conservation of the species in the field and eliminating the threat of extinction. In addition, the results of this study also indicate the strong impact that climate change can have on the populations of these cacti in their natural environment, reducing their populations due to the progressive increase of temperature and the reduction of water availability in the soil.

\section{References}

ABUD, H.F.; PEREIRA, M.F.; GONÇALVES, N.R.; PEREIRA, D.S.; BEZERRA, A.M.E. Germination and morphology of fruits, seeds and plants of Cereus jamacaru DC. Journal of Seed Science, v.35, n.3, p.310-315, 2013. http://www.scielo.br/pdf/jss/v35n3/06.pdf.

AYRES, M.; AYRES JR., M.; AYRES, D.L.; SANTOS, A.A.S. BioEstat 5.0 - Aplicações estatísticas nas áreas das ciências biológicas e médicas. Belém: Instituto de Desenvolvimento Sustentável Mamirauá, 2007. 364p.

BASKIN, C.C.; BASKIN, J.M. Seeds: Ecology, Biogeography, and Evolution of Dormancy and Germination. San Diego: Academic Press, 2014. 1586p. 
BRACCINI, A.L.; RUIZ, H.A.; BRACCINI, M.C.L.; REIS, M.S. Germinação e vigor de sementes de soja sob estresse hídrico induzido por soluções de cloreto de sódio, manitol e polietileno glicol. Revista Brasileira de Sementes, v.18, n.1, p.10-16, 1996.

BRASIL. Ministério do Meio Ambiente. Mapas de Cobertura Vegetal dos Biomas Brasileiros. Ministério do Meio Ambiente. Brasília: 2006. 16p. http://www.mma.gov.br/estruturas/sbf_chm_ rbbio/_arquivos/mapas_cobertura_vegetal.pdf

CHEIB, A.L.; GARCIA, Q.S. Longevity and germination ecology of seeds of endemic cactaceae species from high-altitude sites in southeastern Brazil. Seed Science Research, v.22, n.1, p.45-53, 2012. https://doi.org/10.1017/S0960258511000298.

FASSBENDER, H.W.; BORNEMISZA, E. Quimica de suelos con énfasis en suelos de América Latina. San José: Instituto Interamericano de Cooperación para la Agricultura, 1987. 420p.

FLORES, J.; JURADO, E.; CHAPA-VARGAS, L.; CERONISTUVA, A.; DÁVILA-ARANDA, P.; GALÍNDEZ, G.; GURVICH, D.; LEÓN-LOBOS, P.; ORDÓÑEZ, C.; ORTEGA-BAES, P.; RAMÍREZ-BULLÓN, N.; SANDOVAL, A.; SEAL, C. E.; ULLIAN, T.; PRITCHARD, H. W. Seeds Photoblastism and its Relationship with Some Plant Traits in 136 Cacti Taxa. Environmental and Experimental Botany, v.71, n.1, p.79-88, 2011. http://www. sciencedirect.com/science/article/pii/S0098847210002236

GURVICH, D.E.; FUNES, G.; GIORGIS, M.A.; DEMAIO, P. Germination characteristics of four argentinean endemic Gymnocalycium (Cactaceae) species with different flowering phenologies. Natural Areas Journal, v.28, n.2, p.104-108, 2008. http:// dx.doi.org/10.3375/0885-8608(2008)28[104:GCOFAE]2.0.CO;2.

MACHADO, M.C.; ZAPPI, D.C.; TAYLOR, N.P.; BORBA, E.L. Taxonomy and Conservation of the Discocactus Pfeiff. (Cactaceae) Species Occurring in the State of Bahia, Brazil. Bradleya, v.23, n.1, p.41-56, 2005. https://www.researchgate.net/publication/282365964

MARQUES, F.R.F.; MEIADO, M.V.; CASTRO, N.M.C.R.; CAMPOS, M.L.O.; MENDES, K.R.; SANTOS, O.O.; POMPELLI, M.F. GerminaQuant: a new tool for germination measurements. Journal of Seed Science, v.37, n.3, p.248-255, 2015. http://www. scielo.br/pdf/jss/v37n3/2317-1537-jss-37-03-00248.pdf

MARTINS, L.S.T.; PEREIRA, T.S.; CARVALHO, A.S.R.; BARROS, C.F.; ANDRADE, A.C.F. Seed germination of Pilosocereus arrabidae (Cactaceae) from a semiarid region of South-East Brazil. Plant Species Biology, v.27, n.3, p.191-200, 2012. http://onlinelibrary.wiley. com/doi/10.1111/j.1442-1984.2011.00360.x/abstract.

MASCARENHAS, J.C.; BELTRÃO, B.A.; SOUZA JUNIOR, L.C.; GALVÃO, M.J.T.G.; PEREIRA, S.N.; MIRANDA, J.L.F. Projeto Cadastro de Fontes de Abastecimento por Água Subterrânea Diagnóstico do Município de Serra Talhada, Estado de Pernambuco. Recife: CPRM - Serviço Geológico do Brasil, 2005. 12p.

MEIADO, M.V. Germinação de sementes de cactos do Brasil: fotoblastismo e temperaturas cardeais. Informativo ABRATES, v.22, n.5, p.20-23, 2012.
MEIADO, M.V. Seed Germination of Melocactus sergipensis N.P. Taylor \& M.V. Meiado, the Newest Brazilian Cactus destined for extinction. Plant Species Biology, v.31, n.4, p.296-299, 2016. http:// onlinelibrary.wiley.com/doi/10.1111/1442-1984.12106/abstract.

MEIADO, M.V.; ALBUQUERQUE, L.S.C.; ROCHA, E.A.; ROJASARÉCHIGA, M.; LEAL, I.R. Seed germination responses of Cereus jamacaru DC. ssp. jamacaru (Cactaceae) to environmental factors. Plant Species Biology, v.25, n.2, p.120-128, 2010. http://onlinelibrary. wiley.com/doi/10.1111/j.1442-1984.2010.00274.x/abstract.

MEIADO, M.V.; LIMA, A.T.; NASCIMENTO, J.P.B.; AONA, L.Y.S. Avanços nos estudos sobre sementes e plântulas de cactos do Brasil. Gaia Scientia, v.11, n.1, p.1-10, 2017. http://periodicos.ufpb. br/ojs2/index.php/gaia/article/view/35473

MEIADO, M.V.; MACHADO, M.C.; ZAPPI, D.C.; TAYLOR, N.P.; SIQUEIRA FILHO, J.A. Cacti of the São Francisco Watershed: Ecological Attributes, Geographic Distribution and Endemism. In: SIQUEIRA FILHO, J.A. (Org.). Flora of the Caatingas of the São Francisco River: Natural History and Conservation. Rio de Janeiro: Andrea Jakobsson Estudio Editorial, 2012a. p.264-305.

MEIADO, M.V.; SILVA, F.F.S.; BARBOSA, D.C.A.; SIQUEIRAFILHO, J.A. Diaspore of the Caatinga: A Review. In: SIQUEIRA FILHO, J.A. (Org.). Flora of the Caatingas of the São Francisco River: Natural History and Conservation. Rio de Janeiro: Andrea Jakobsson Estudio Editorial, 2012b. p.306-365.

MEIADO, M.V.; ROJAS-ARÉCHIGA, M.; SIQUEIRA FILHO, J.A.; LEAL, I.R. Effects of light and temperature on seed germination of cacti of brazilian ecosystems. Plant Species Biology, v.31, n.2, p.87-97, 2016. http://onlinelibrary.wiley.com/doi/10.1111/14421984.12087/abstract.

ORTEGA-BAES, P.; GALÍNDEZ, G.; SÜHRING, S.; ROJASARÉCHIGA, M.; DAWS, M.I.; PRITCHARD, H.W. Seed germination of Echinopsis schickendantzii (Cactaceae): the effects of constant and alternating temperatures. Seed Science and Technology, v.39, n.1, p.219-224, 2011. http://www.ingentaconnect. com/contentone/ista/sst/2011/00000039/00000001/art00021.

ORTEGA-BAES, P.; ROJAS-ARÉCHIGA M. Seed Germination of Trichocereus terscheckii (Cactaceae): Light, temperature and gibberellic acid effects. Journal of Arid Environments, v.69, n.1, p.169-176, 2007. http://www.sciencedirect.com/science/article/pii/ S0140196306002710.

RAMÍREZ-PADILLA, C.A.; VALVERDE T. Germination Responses of three congeneric cactus species (Neobuxbaumia) with differing degrees of rarity. Journal of Arid Environments, v.61, n.2, p.333-343, 2005. http://www.sciencedirect.com/science/article/pii/ S0140196304001983.

ROJAS-ARÉCHIGA, M.; MANDUJANO, M.C. Avances en los estudios sobre la germinación de cactáceas mexicanas. In: LOIOLA, M.I.B.; BASEIS, I.G.; LICHSTON, J.E., (Orgs.). Atualidades, desafios e perspectivas da Botânica no Brasil. Natal: Imagem Gráfica, 2008. p.460-462.

ROJAS-ARÉCHIGA, M.; MANDUJANO, M.C.; GOLUBOV, J.K. Seed size and photoblastism in species belonging to tribe cacteae (Cactaceae). Journal of Plant Research, v.126, n.3, p.373-386, 2013. https://link.springer.com/article/10.1007/s10265-012-0526-2. 
ROJAS-ARÉCHIGA, M.; OROZCO-SEGOVIA, A.; VÁZQUEZYANES, C. Effect of light on germination of seven species of cacti from Zapotitlán Valley in Puebla, México. Journal of Arid Environments, v.36, n.4, p.571-578, 1997. http://www.sciencedirect. com/science/article/pii/S0140196396902189.

ROJAS-ARÉCHIGA, M.; VÁZQUEZ-YANES, C. Cactus seed germination: A Review. Journal of Arid Environments, v.44, n.1, p.85-104, 2000. http://www.sciencedirect.com/science/article/pii/ S0140196399905827.

ROJAS-ARÉCHIGA，M.; VÁZQUEZ-YANES，C.; OROZCOSEGOVIA, A. Seed response to temperature of mexican cacti species from two life forms: an ecophysiological interpretation. Plant Ecology, v.135, n.2, p.207-214, 1998. https://link.springer. com/article/10.1023/A:1009757227493.

SANTOS, M.R.; MACHADO, M.C.; GARCIA, F.C.P.; TAYLOR, N.P. Taxonomic adjustments in Discocactus Pfeiff. (Cactaceae). Phytotaxa, v.207, n.2, p.209-212, 2015. http://biotaxa.org/Phytotaxa/ article/view/phytotaxa.207.2.9.

SOUZA, L.F.; GASPARETTO, B.F.; LOPES, R.R.; BARROS, I.B.I. Temperature requirements for seed germination of Pereskia grandifolia.Journal of ThermalBiology, v.57,n.1,p.6-10,2016.http:// www.sciencedirect.com/science/article/pii/S0306456515301303.
TAYLOR, N.; ZAPPI, D. Cacti of Eastern Brazil. Royal Botanic Gardens, Kew, 2004. 499p.

VILLELA, F.A.; DONI FILHO, L.; SEQUEIRA E.L. Tabela de potencial osmótico em função da concentração de Polietileno Glicol 6.000 e da temperatura. Pesquisa Agropecuária Brasileira, v.26, n.11/12, p.1957-1968, 1991. https://seer.sct.embrapa.br/index.php/ pab/article/view/3549/882.

ZAPPI, D., TAYLOR N.; MACHADO, M.; SANTOS, M.R. Ameaças. In: RIBEIRO-SILVA, S., ZAPPI, D.C., TAYLOR, N.P., MACHADO, M.C. (Orgs.). Plano de Ação Nacional para a Conservação das Cactáceas - Série Espécies Ameaçadas $n 24$. Brasília: Instituto Chico Mendes de Conservação da Biodiversidade, 2011. p.53-55.

ZAPPI, D.; TAYLOR, N.; SANTOS, M.R.; LAROCCA, J. Cactaceae. Lista de Espécies da Flora do Brasil. [homepage of the Internet]. Jardim Botânico do Rio de Janeiro, Rio de Janeiro, 2017. http://floradobrasil.jbrj.gov.br/jabot/floradobrasil/FB700.

ZAR, J.H. Biostatistical analysis. Prentice Hall Inc., New Jersey, 2010. 960p. 